\title{
The Relationship of Servant Leadership in the Classroom and Student Perceptions of University Quality of Instruction
}

\author{
Jack McCann \\ School of Business, Tusculum College, \\ Greenville, TN, United States; \\ Betsy Sparks \\ School of Business and Technology, \\ South College, Knoxville, TN, United States;
}

\begin{abstract}
In this study, we examined students' perceptions of certain servant leader behaviors exhibited by faculty and the associated perception of effective university instruction. Five servant leadership dimensions were considered: altruistic calling, emotional healing, wisdom, persuasive mapping, and organizational stewardship. Students in the United States who were in undergraduate or graduate programs or had completed a program within the last month were invited to complete the survey instrument based on the Servant Leadership Questionnaire developed by Barbuto and Wheeler [1] and the University of Winnipeg's Quality of University Instruction Questionnaire (UWQUIQ) developed by Clark [4]. We used a structural equation model and found there was a positive relationship with professors exhibiting servant leadership dimensions and quality of instruction. Business professors in this study exhibited lower servantleadership attributes in some areas and lower levels of effective university instruction than their counterparts, mandating the need for change. We suggest that these results provide insight into improving business school instruction.
\end{abstract}

Keywords: Servant leadership, Quality of Instruction.

\section{INTRODUCTION}

The ability of higher education to adapt the classroom to an ever-changing environment impacted by government regulations and a demanding economy is based on the need for institutions to change. Unfortunately, change is slow and methodical in higher education [15]. Institutions of higher learning must adapt their processes and systems using a specific form of leadership. This leadership style must be developed in the boundaries where higher education meets society [7]. If higher education applies the principles, values, and practices of Servant Leadership to teaching, this will dramatically impact learning and the learning experiences of both students and professors [11].

In this study, we determined the level of servant leadership in higher education as perceived by students in programs of study and graduates who completed their programs within the last month. Also, we examined the perceptions of university instruction to gather additional baseline data to understand better what students think of their instruction. Finally, we examined dimensions of servant leadership and the quality of university instruction to determine where relationships exist.

Our research questions were as follows:

1. What is the level of servant-leadership attributes exhibited by professors in university classrooms?

2. What are the perceptions of quality of university instruction by students? 
3. What is the relationship between servant-leadership attributes and perceptions of the quality of university instruction?

To validate the research questions, we will present a short literature review, with the purpose of establishing a framework of the current understanding of servant leadership and quality of instruction in the classroom. Next, we will thoroughly describe the concept of servant leadership along with other theories of leadership and management in the higher education classroom. Finally, we will present our conclusions and discussion of findings to establish if there is a need to change the approach in which leadership is used in the higher education classroom.

\section{Servant Leadership}

Robert Greenleaf, AT\&T's former director of management research and founder of the Robert K. Greenleaf Center for Servant Leadership, wrote an essay proposing the idea of servant leadership as a theory [9]. He modeled servant leadership on the character, Leo, in the story Journey to the East, written by Herman Hesse. Leo is the servant for a group traveling across the desert and does everything for the group by serving them in any way that they need, and then he disappears. The group finally realizes that Leo was not their servant, he was their leader and led by serving them. Greenleaf [9] carefully considered this paradox and described his leadership philosophy as it applies to classroom instruction when you consider the teacher as a servant:

It begins with the natural feeling that one wants to serve, to serve first. Then conscious choice brings one to aspire to lead. The difference manifests itself in the care taken by the servant-first to make sure that other people's highest priority needs are being served. The best test is: Do those served grow as persons; do they, while being served, become healthier, wiser, freer, more autonomous, more likely themselves to become servants? ( $p .4)$

Greenleaf [10] referred to servant leadership as leadership that places serving the needs of others first. The servant leader in the classroom serves their students through the high standards of servant leadership in the process of teaching and learning. This theory taps into the natural feeling that one desires to serve others first. A conscious choice then brings one to aspire to lead. The true test of the existence of servant leadership in the classroom is whether those served grow as people: Do those being served become healthier, wiser, freer, more autonomous, more likely themselves to become servants? The characteristics of servant leadership apply to the process of teaching and learning. Spears [18] described a list of ten characteristics about servant leadership from Greenleaf's writings and adapted for effective teaching and learning in higher education which are shown below:

1. Listening-Servant leaders focus on listening intently and reflectively to their students and others.

2. Empathy-Servant leaders strive to understand and empathize with students and others.

3. Healing-Servant leaders learn how to heal difficult situations in the classroom and school.

4. Awareness-Servant leaders are generally self-aware.

5. Persuasion-Servant leaders focus on using persuasion versus authority.

6. Conceptualization-Servant leaders nurture their student's ability to dream.

7. Foresight-Servant leaders foresee situations in the classroom.

8. Stewardship-Servant leaders hold their students and school responsible for the overall good of society. 
9. Sense of Community-Servant leaders build a sense of community in their classroom and school.

10. Commitment to Growth of People-Servant leaders believe that students have more to offer than just in the classroom. (p. 2)

Hays [11] presented narratives from student learning journals about how these characteristics were applied in the classroom. The following excerpts from his research are included to share the perceptions of students about servant leadership. These narratives are extracted from student reflective learning journals, interviews, and unsolicited comments from students in management courses. Their instruction can be characterized as having one or more of the attributes of formal learning objectives or as integral to the instructional strategy or instructor's approach. Hays [11] found the following student perceptions of servant leadership behaviors:

\section{Listening}

What I observed is that he really listens to us. He listens so carefully, and really tries to understand what we are saying. He never makes us feel foolish or wrong when we respond to or even ask a question. He makes the best out of comments we make. Everybody wants to participate, because he cares so much about what we have to say! (p. 123-124)

\section{Empathy}

I'm coming to see that the problems we are having [in my team] at work are not because my people are careless or unmotivated. I realize now that the reason they are struggling so much and so often get into conflicts with one another is due in part to my own leadership style and the way we are organized. Where I previously thought they were incapable of ever working well together, I accept that I have done little to help them. In fact, my reactive and sometimes aggressive behavior is making the matter worse. I'm going to stop blaming them so much, and start to look at my own behavior and how I might be more supportive. The first thing I'm going to do is start to more honestly seek feedback from my team members and try to change myself and the way we work. (p. 124)

\section{Healing}

...[Instructor's] lectures were different from day one. Everybody has a voice. We know that our opinions count and that she will try to accommodate our needs. She makes us feel good about coming to lecture. Now, half way through, it's like everybody wants to talk, all the time. It's funny, and helpful, to hear what all the different students have to say. How can there be so many interpretations of the same thing? (p. 124)

\section{Persuasion}

At first, I wondered why [instructor] talked about himself all the time. I thought he was arrogant. I wished he would just get on with the lesson and emphasize things from the textbook that were important. I probably missed most of the lesson because I was so preoccupied with these thoughts, and was growing angrier and more frustrated. Then all of the sudden, things started making sense. I realized he wasn't just talking about himself. He was talking about people, leaders, organizations; things that make a difference in the management context. In fact, I realize now that I had no concept of what "management context" was until I started listening more intently and trying to find the applications and examples [instructor] is always talking about. He was talking about me! What am I going to do in that situation? It's not about what he would do; it's about knowing myself and my values and understanding how I fit in my organization. How am I going to decide what to do? Am I going to be able to make a difference? Do I care? (p. 125) 


\section{Awareness}

I could see that Professor [instructor] had Wednesday's lesson prepared. While not particularly inspiring, the first few slides shown made sense and reinforced the chapter I had read beforehand. A quick look around the room showed students already looking bored or sleepy. I figured this would be another typical lecture. Since I was doodling and kind of lost in my own thoughts, it took me a few moments to realize that Professor [instructor] had turned the lights up a shade and moved forward from behind the lectern. (p. 126)

\section{Conceptualization}

...But now I'm seeing everything through these systems thinking eyes: this course is a system. Even lectures are a system. [Instructor] teaches the way he does because of his understanding of the system (if I want to give him the credit) or he teaches the way he does because he is an element of the system and responding to it as the system design would predict! My football team is a system and part of a much bigger system! I'm starting to get it. Problems and conflicts are systems, and can only be solved or changed when understood and approached as a system. (p. 127)

\section{Foresight}

Dr. [instructor] is fully committed to her style of teaching. Even when students are obviously dissatisfied with the way things are going, she sticks to her guns. I admire her courage and stick-toitiveness. It would be much easier to just go along with students. I mean, they are really just asking for things to be like they are in other courses (predictable, structured, consistent). They want clear guidance and direction. I do to. Doesn't everybody? Yet, I'm starting to get a sense that we are on about something bigger than management, or maybe that management is much bigger than I thought it was.

Maybe organizations and work are less predictable and rational than I have been led to believe. Maybe the chaos and confusion we feel in this course is like the real world. If so, then we are getting a first-hand experience of it... Don't know if that is a fair course objective...

If control is an important aspect of management, then shouldn't we see more evidence of effective control in the course? Maybe we are supposed to learn to manage out of this mess ourselves? (p. 126)

\section{Stewardship}

...our team has been struggling since the beginning. ...This course has helped me see why teams fail and what they need to succeed, and it has changed my views a bit. For example, I used to think that strong leadership was the essence of a successful team, and that you had to hand pick people who were highly motivated and would pull their weight. I see now that teamwork is much more than that. You have to have a process for working together. These processes require skills and discipline. Team members need to be able to adapt to changing situations, understand problems, make decisions, and work together, not just independently. When we came to you to fix our problem, you helped us work through it and made us see that it was our responsibility, not yours. It was a team problem, not an individual's one... (p. 129)

\section{Sense of Community}

It's the sixth week of the semester. We are almost half way through. I'm still trying to figure out where you are coming from. I mean, lectures are interesting and different; sometimes even fun. But I wonder if we're learning anything? We hardly ever focus on the chapter readings. I wonder how you can test us on what we're learning, and I'm worried how I'll do on the final 
exam. Some of the other students are grumbling; one or two have been very critical of your approach. Somehow I feel they are being unfair; yet, I can't really argue with them. So, I've been keeping my thoughts to myself. It's good to have my journal to reflect in. Maybe I'll come to some kind of $a$ ha! point, as I continue to think about this. (p. 129)

\section{Commitment to Growth of People}

Several times during the semester Dr. [instructor] sought our feedback on the course and his teaching. He is the first teacher or lecturer I've ever had that really did this. We spent half the class one evening evaluating and discussing the course because so much came out of one of the feedback sessions. More than once someone raised an issue that seemed really critical. Dr. [instructor] would make the critical student feel good about giving negative feedback, and he would try to find out more. He incorporated changes when he could, like changing the assessment deadline or writing session objectives on the board and reviewing them at the end. This shows everyone that their opinions count and that they won't be penalized for speaking up about something they don't agree with. (p. 128)

Servant leadership calls for leading from a revolutionary vision where leaders change the organization, invent the new paradigm, and clear space where something new can be accomplished [21]. Servant leadership can also be considered a philosophy of life and leadership dedicated to the growth and development of others. The servant leader in the classroom is committed to building students, classrooms, and schools that are value-based and that ultimately contribute to creating organizations that are sustainable, ethical, and socially concerned, which can be achieved through the application of servant leadership in the classroom, school, and life. Servant leadership is related to successful outcomes and positive perceptions of quality university instruction.

\section{Teacher as Servant-leader}

According to Bowman [6], servant leadership by teachers is a personal choice and starts from within the teacher and can externally influence the classroom and the organization [6]. A comparison between the qualities of a good teacher by Beidler [2], the qualities of a serving leader by Jenning and Stahl-Wert [12], and the explanation as to how the qualities of a serving leader are related to a teacher's perspective by Bowman [6], as adapted from Scardino [17] are shown in Table 1. 
Table 1. Comparison of a Good Teacher, Serving Leader, and Teacher as a Servant.

\begin{tabular}{|c|c|}
\hline Categories & Qualities \\
\hline Qualities of a Good Teacher & $\begin{array}{l}\text { Good teachers seize every moment to do out-of- } \\
\text { classroom tasks such as checking papers and } \\
\text { attending to student consultations. Good teachers } \\
\text { aspire to be good teachers. } \\
\text { Good teachers try to motivate students by employing } \\
\text { an incentive system. Good teachers take risks in } \\
\text { classroom teaching innovations. Good teachers } \\
\text { challenge their students to move out of their comfort } \\
\text { zones. Good teachers have a positive attitude. Good } \\
\text { teachers think of teaching as a form of parenting. } \\
\text { Good teachers listen to their students. [2] }\end{array}$ \\
\hline Teachers as Servant-leaders & $\begin{array}{l}\text { Teachers as servant leaders are committed to } \\
\text { inspiring their students and colleagues. Teachers as } \\
\text { servant leaders remove hindrances to student } \\
\text { development. Classroom teachers as serving leaders } \\
\text { help not only their students, but also their peers to } \\
\text { succeed. Teachers as serving leaders fervently and } \\
\text { proficiently teach the knowledge, skills, and } \\
\text { strategies that students need to succeed. Teachers as } \\
\text { serving leaders serve as role models professionally } \\
\text { and attitudinally for their students. Teachers as } \\
\text { serving leaders help students overcome their } \\
\text { weaknesses to achieve better performances. } \\
\text { Teachers expound on the strengths of their students } \\
\text { to make them excel in what they do. Teachers as } \\
\text { serving leaders start by listening to the hopes of } \\
\text { others, so that they can lead by being led. Teachers as } \\
\text { serving leaders seize daily opportunities to make } \\
\text { subtle differences in their students' lives over time. } \\
\text { [6] }\end{array}$ \\
\hline Qualities of a serving leader & $\begin{array}{l}\text { Serving leaders have a natural feeling that one truly } \\
\text { wants to serve first and lead secondly. They unleash } \\
\text { the strength, talents, and passions of those they serve. } \\
\text { They establish a high standard of performance for } \\
\text { those served, and address the weakness and build on } \\
\text { the strengths of those they serve. They put } \\
\text { themselves at the bottom of the pyramid, so they can } \\
\text { focus on unleashing the energy, excitement, and } \\
\text { talents of those being served. [12] }\end{array}$ \\
\hline
\end{tabular}

A core principle of servant leadership is accountability. The creation and maintenance of positive faculty-student relationships are necessary for holistic and shared objectives and accountability [6]. Furthermore, educators are encouraged to promote community awareness, connection, interdependence, fairness, and the sharing of power to enhance social relationships in the classroom. Bowman [6] said that servant leaders as teachers must have an understanding of teaching styles and preferences and how they impact student learning. 


\section{Sample and Data Collection}

\section{METHODOLOGY}

To elicit a greater sample size and enhance the estimation of our model, we distributed the survey to college students in the United States through Survey Monkey (www.surveymonkey.com). The criteria for inclusion were that students must be in undergraduate or graduate programs or have completed a program within the last month. Survey Monkey uses regular benchmarking surveys to ensure that members are adequately representative of the requested population. Each member is offered small non-cash awards for completion (i.e., charitable donations or sweepstakes entries). Over 932 students opened the survey which resulted in 802 useable responses. The overall abandonment rate was 14.1\% with a survey span of approximately two weeks. The sample consisted of business students and students from other majors. Incomplete responses with more than $5 \%$ missing values, and two responses exhibiting straight lining were eliminated. Table 2 shows the demographics of our sample.

Table 2. Demographics of Sample.

\begin{tabular}{|l|l|l|}
\hline Characteristic & Number & Frequency \\
\hline Professors Evaluated & & \\
\hline Adjunct & 149 & $18.6 \%$ \\
\hline Full-time & 653 & $81.4 \%$ \\
\hline Gender of Professor Evaluated & & \\
\hline Male & 582 & $72.6 \%$ \\
\hline Female & 220 & $27.4 \%$ \\
\hline Department of Course for Professor Evaluated & & \\
\hline Business & 304 & $37.9 \%$ \\
\hline Other & 498 & $62.1 \%$ \\
\hline Class Standing of Student Performing Evaluation & & \\
\hline Undergraduate & 375 & $46.8 \%$ \\
\hline Graduate & 427 & $53.2 \%$ \\
\hline
\end{tabular}

\section{Instruments}

We used the Servant Leadership Questionnaire (SLQ) and University of Winnipeg's Quality of University Instruction Questionnaire (UW-QUIQ) for measuring the dimensions of servant leadership and quality of instruction. The first section of the survey was the Servant Leadership Questionnaire (SLQ) from the research by John E. Barbuto, Jr. and Daniel Wheeler [1] entitled "Scale Development and Clarification of Servant Leadership." The authors of the SLQ granted permission for use in this research. This SLQ is currently being used by academic researchers to measure servant leadership.

In the process of validating the Servant Leadership Questionnaire, Barbuto and Wheeler [1], identified a factor structure consisting of five dimensions and ten subscales. They created items using the contents of servant leadership as presented by Spears [18] and adding 
additional elements as identified by the authors as relevant to the study of servant leadership. Barbuto and Wheeler [1] performed a series of exploratory factor analyses using varimax rotation with Kaiser normalization and oblique rotations with which resulted in 23 items retained with internal reliability measured by Cronbach's alpha values between .82 and .92 for the rater version of the survey. Their confirmatory factor analysis using maximum likelihood indicated that the 23 retained items for the five latent variables were a good fit $\left(\chi^{2}(220)\right.$ $=1410.69, p<.01$ ); root mean square error of approximation was .01; and normed fit index, non-normed fit index, comparative fit index, relative fit index, and incremental fit index all exceeded .95. The factors in the rater version were highly related to each other. The respondents included in the validation process consisted of 388 colleagues of 80 elected community leaders who completed the rater version of the SLQ. Dannhauser and Boshoff [8] conducted a study on the structural equivalence of the Barbuto's and Wheeler's SLQ and found some level of portability in their sample of South African employees working in the automotive retail industry.

We used the University of Winnipeg's Quality of University Instruction Questionnaire (UWQUIQ), authored by James M. Clark [4], to measure the quality of instruction. In Clark's research, he reviewed techniques that instructors might use to improve their classroom teaching. The techniques are drawn primarily from empirical research on university teaching and are organized around the clusters measured by U of W's Quality of University Instruction Questionnaire (UW-QUIQ).

Clark's research to develop the survey applies to many types of university teaching, and he notes that instruction cannot be defined in any absolute way [4]. He further stated that University teaching involves diverse modes of instruction, including lectures, seminars, labs, simulations, internships, and mentoring (e.g., thesis supervision). Disciplines, courses, and instructors also vary widely in their emphasis on educational objectives such as learning new knowledge, stimulating student interest, developing cognitive skills, and leading students to question established tenets. One important distinction in determining effective teaching may be the relative importance of cognitive and affective goals. That is, some qualities of teaching may be more strongly related to such cognitive objectives as developing knowledge and skills; whereas other qualities are more strongly related to such affective objectives as fostering student interest and curiosity. The clusters and ideas developed for the instrument are not meant to be exhaustive and should not prevent alternative methods from being used by effective instructors. There is no formula or cookbook for effective university teaching.

Clark [4] maintained that these sources of variation preclude a single model for effective instruction. Various teaching qualities nonetheless are associated with the achievement of different cognitive and affective goals and probably contribute to the quality of university teaching across a wide range of conditions. The qualities examined here were identified by researchers using student evaluations, trained observers in classrooms, verbal reports by teachers and students, and the training of teachers in specific teaching skills. The qualities are also generally consistent with psychological theories about learning (e.g., the role of prior knowledge and importance of organization) and with common-sense intuitions about the qualities of effective university teachers.

The taxonomy of the clusters of items on the UW-QUIQ is presented below in Table 3. Clark [4] indicated that the classification is rough, in that some of the clusters are not very homogeneous (i.e., they include diverse teaching behaviors); some categories overlap (i.e., teaching behaviors are related to multiple objectives); and the taxonomy may not be exhaustive (i.e., certain 
aspects of teaching may be inadequately represented). This scheme provides a useful taxonomy for determining the quality of university teaching. The qualities measured by the UW-QUIQ have been divided into aspects of teaching related to cognitive or affective aspects of instruction. Our complete instrument for this research is shown in Appendix A.

Table 3. Qualities of University Instruction.

\begin{tabular}{|l|l|}
\hline Classification & Teaching Behaviors \\
\hline Cognitive & Knowledge and Appreciation \\
\hline & Organization of Individual Lessons \\
\hline & Clarity of Explanations \\
\hline Affective & Quality of Presentation \\
\hline & Stimulation of Interest \\
\hline & Participation and Openness to Ideas \\
\hline & Rapport and Concern \\
\hline & Disclosure and Fairness \\
\hline
\end{tabular}

\section{Data Analysis}

We used descriptive statistics and ANOVA tests to examine the level of servant leadership exhibited by professors and the perception of university instruction by students for the first two research questions. For the third research question, we used structural equation modeling (SEM) with maximum likelihood estimation. We used the software packages IBM SPSS version 23 and Amos 23.0.0 for statistical analysis. We measured the five leadership subscales altruistic calling, emotional healing, wisdom, persuasive mapping, and organizational stewardship - for servant leadership. We measured the quality of instruction using knowledge and appreciation, lesson organization, clear expectations, clear presentations, stimulating interest, participation, and openness to new ideas, rapport and concern, and communication and fairness.

\section{Data Validity and Common Method Bias}

An assumption in covariance based Structural Equation Modeling (SEM) is that the data are normally distributed. We calculated the skewness and kurtosis of each item using SPSS to assess normality. Skewness ranged from -1.62 to -0.76 and kurtosis ranged from -1.15 to 0.62 which are less than 2.0 and considered in an acceptable range, indicating no problems with the normality assumption. We conducted exploratory factor analysis (EFA) using a maximum likelihood promax estimation method to compute goodness of fit for the servant leadership measurement model and also a confirmatory factor analysis (CFA) to assess the reliability and validity of the servant leadership measurement instrument. We chose maximum likelihood since the data did not exhibit problems with the normality assumption. The EFA indicated issues with the items two items measuring persuasive mapping and one item measuring wisdom, as they did not load onto the appropriate factors. Since there were other indicators for these leadership variables, we eliminated these items from the structural equation model. One item for rapport and concern and one item for communication and fairness exhibited communalities of .38 and .34 respectively indicating possible correlation with other items. We also eliminated these items from the final analysis. For the EFA, all items relating to the quality of instruction were grouped so that there were no one-factor items.

The CFA indicated that the servant leadership measurement model had a satisfactory fit $\left(\chi^{2} / \mathrm{df}\right.$ $=2.32$, comparative fit index $(\mathrm{CFI})=.96$, Tucker-Lewis Index (TLI) $=0.95$, root mean square error of approximation (RMSEA) $=0.041$ ). According to Bentler [3], a CFI greater than .95 indicates a good fit, so our model is a good fit. The TLI is close to 1 and RMSEA is around .05 indicating a good fit [19][20]. 
We used the average variance extracted (AVE) to examine convergent validity. All constructs exceeded the 0.50 recommended values, and all factor loadings exceeded .70 . All Cronbach's alpha values exceeded .70. Composite reliability scores exceeded .95, indicating internal consistency reliability. A Harman's single-factor test with unrotated factor solution indicated $41.68 \%$ of explained variance in the largest factor. This was less than $50 \%$ indicating no problem with common method bias [13].

\section{RESULTS}

Table 4 shows the means and standard deviations for different demographic groups for the servant-leadership attributes exhibited by professors, as perceived by the students completing the survey. Based on the statistics shown in Table 4, the sample of student perception of servant leadership attributes in professors indicated higher means in emotional healing and persuasive mapping than other servant leadership traits. We conducted ANOVA analyses in SPSS to compare the mean ratings between similar groups to determine if statistically significant differences existed. Graduate students indicated that their professor evaluated showed a higher level of altruistic traits $(\mathrm{F}=13.42, p<.01)$, wisdom traits $(\mathrm{F}=7.76, p<.01)$, organizational stewardship ( $\mathrm{F}=9.36, p<.01)$, and performance mapping traits $(\mathrm{F}=6.47, p<.05)$ than undergraduate students' perceptions of these same servant leadership traits in their professors. There was no significant $(p<.05)$ difference in the servant leadership traits for adjunct and full-time professors and no significant difference for male and female professors. Students evaluating professors in other courses rather than business courses rated their professors higher on altruistic traits $(\mathrm{F}=7.86, p<.01)$ and emotional healing traits $(\mathrm{F}=4.72, p<$ .05 ) than students in business courses. There were no significant differences in other servant leadership traits in other courses versus business courses. 
Table 4. Means and Standard Deviations for Servant Leadership Traits by Group.

\begin{tabular}{|c|c|c|c|c|c|c|c|c|c|c|}
\hline \multirow[b]{2}{*}{ Group/Size } & \multicolumn{2}{|c|}{ Altruistic } & \multicolumn{2}{|c|}{$\begin{array}{l}\text { Emotional } \\
\text { Healing }\end{array}$} & \multicolumn{2}{|c|}{ Wisdom } & \multicolumn{2}{|c|}{$\begin{array}{l}\text { Organizational } \\
\text { Stewardship }\end{array}$} & \multicolumn{2}{|c|}{$\begin{array}{l}\text { Persuasive } \\
\text { Mapping }\end{array}$} \\
\hline & Mean & $\begin{array}{l}\text { Std } \\
\text { Dev }\end{array}$ & Mean & $\begin{array}{l}\text { Std } \\
\text { Dev }\end{array}$ & Mean & $\begin{array}{l}\text { Std } \\
\text { Dev }\end{array}$ & Mean & $\begin{array}{l}\text { Std } \\
\text { Dev }\end{array}$ & Mean & Std Dev \\
\hline \multicolumn{11}{|c|}{ Professors Evaluated } \\
\hline $\begin{array}{l}\text { Adjunct } \\
\text { Professor } \\
(\mathrm{N}=149)\end{array}$ & 2.80 & .81 & 3.26 & .84 & 3.13 & .81 & 2.99 & .81 & 3.26 & .79 \\
\hline $\begin{array}{l}\text { Full-time } \\
\text { Professor } \\
(\mathrm{N}=653)\end{array}$ & 2.89 & .80 & 3.39 & .83 & 3.25 & .79 & 3.08 & .81 & 3.34 & .80 \\
\hline \multicolumn{11}{|c|}{ Gender of Professor Evaluated } \\
\hline $\begin{array}{l}\text { Male Professor } \\
(\mathrm{N}=582)\end{array}$ & 2.87 & .81 & 3.35 & .84 & 3.22 & .80 & 3.06 & .81 & 3.33 & .81 \\
\hline $\begin{array}{l}\text { Female } \\
\text { Professor } \\
(\mathrm{N}=220)\end{array}$ & 2.89 & .79 & 3.40 & .81 & 3.24 & .77 & 3.08 & .81 & 3.32 & .77 \\
\hline \multicolumn{11}{|c|}{ Department of Course for Professor Evaluated } \\
\hline $\begin{array}{l}\text { Business Course } \\
(\mathrm{N}=304)\end{array}$ & 2.97 & .74 & 3.28 & .82 & 3.22 & .77 & 3.13 & .78 & 3.30 & .79 \\
\hline $\begin{array}{l}\text { Other Course } \\
(\mathrm{N}=498)\end{array}$ & 2.81 & .83 & 3.42 & .83 & 2.24 & .81 & 3.02 & .82 & 3.34 & .81 \\
\hline \multicolumn{11}{|c|}{ Class Standing of Student Performing Evaluation } \\
\hline $\begin{array}{l}\text { Undergraduate } \\
\text { Student }(\mathrm{N}=375)\end{array}$ & 2.76 & .80 & 3.32 & .90 & 3.15 & .82 & 2.97 & .83 & 3.25 & .83 \\
\hline $\begin{array}{l}\text { Graduate } \\
\text { Student }(\mathrm{N}=427)\end{array}$ & 2.97 & .79 & 3.40 & .76 & 3.30 & .76 & 3.15 & .78 & 3.39 & .76 \\
\hline $\begin{array}{l}\text { Entire Sample } \\
(\mathrm{N}=802)\end{array}$ & 2.87 & .80 & 3.37 & .83 & 3.23 & .79 & 3.07 & .81 & 3.33 & .80 \\
\hline
\end{tabular}

Table 5 shows the means and standard deviations for the effective teaching measure for the different demographic groups. We calculated the value for effective teaching using the sum of ratings from the Winnipeg's Quality of University Instruction Questionnaire. Based on the statistics shown in Table 5, the sample of student perception of effective teaching was highest among other courses rather than business professors. We compared the mean ratings between similar groups using ANOVA analyses to determine if statistically significant differences existed. There were no significant differences based on student perception of effective teaching between undergraduate students and graduate students, and no significant difference between male and female professors. There was a statistically significant difference between an adjunct 
and full-time faculty $(\mathrm{F}=8.35, p<.01)$, with full-time faculty having a larger mean value of satisfaction. There was also a statistically significant difference between business course professors and other course professors ( $\mathrm{F}=28.14, p<.01)$, with other course professors having a larger mean value of satisfaction.

Table 5. Means and Standard Deviations for Effective Teaching by Group.

\begin{tabular}{|l|c|c|}
\hline Group/Size & Mean & Std Dev \\
\hline Professors Evaluated & & .84 \\
\hline Adjunct Professor (N=149) & 3.49 & .72 \\
\hline Full-time Professor (N=653) & 3.69 & .72 \\
\hline Gender of Professor Evaluated & 3.64 & .75 \\
\hline Male Professor (N=582) & 3.66 & .74 \\
\hline Female Professor (N=220) & 3.47 & .73 \\
\hline Department of Course for Professor Evaluated & .79 \\
\hline Business Course Professor (N=304) & 3.76 & .71 \\
\hline Other Course Professor (N=498) & 3.68 & .77 \\
\hline Class Standing of Student Performing Evaluation & 3.62 & \\
\hline Undergraduate Student (N=375) & 3.70 & \\
\hline Graduate Student (N=427) & & \\
\hline Entire Sample (N=802) & & \\
\hline
\end{tabular}

Figure 1 shows the results of the structural equation model used to examine the relationship between servant leadership attributes and quality of instruction as perceived by the students completing the survey. All paths in the model were significant $(p<.01)$. The model had a satisfactory fit $\left(\chi^{2} / \mathrm{df}=2.89\right.$, comparative fit index $(\mathrm{CFI})=.93$, Tucker-Lewis Index $(\mathrm{TLI})=0.93$, and root mean square error of approximation (RMSEA) $=0.049$ ).

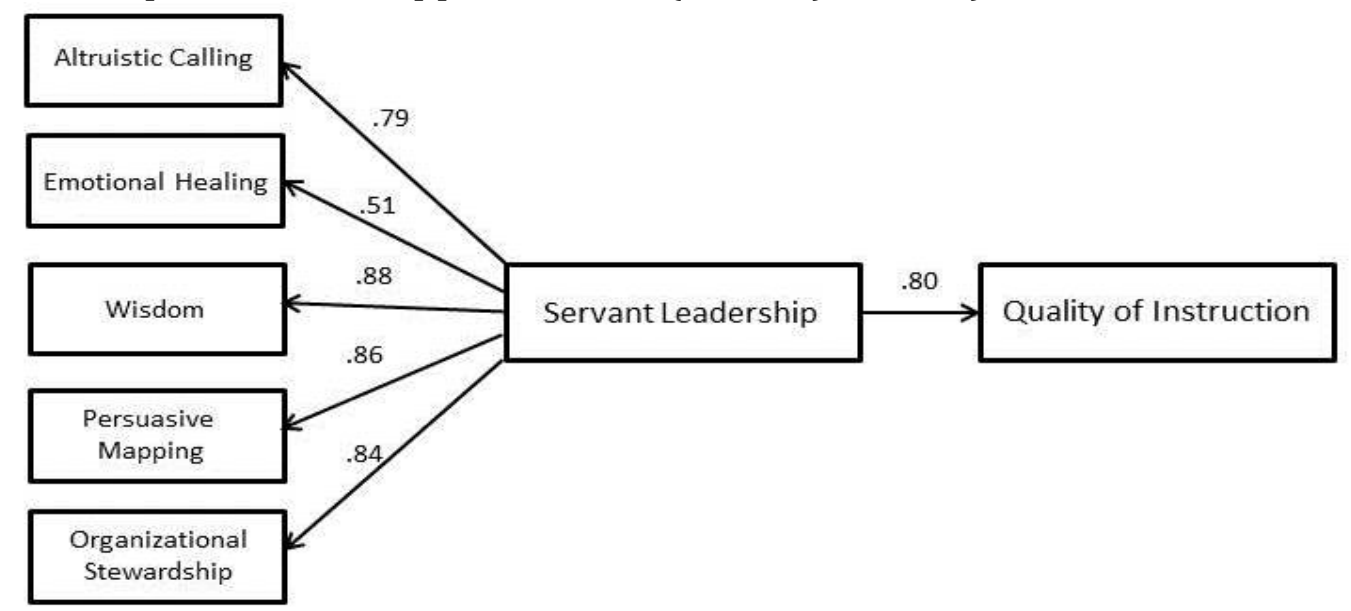

Figure 1. Results of structural equation model with all paths significant $(p<.01)$. 
The model explained $64.7 \%$ of the variance in quality of instruction. The standardized path coefficient from servant leadership to the quality of instruction of .80 was significant $(p<.01)$, indicating that faculty exhibiting servant leadership dimensions were perceived as having a better quality of instruction based on this survey. For servant leadership, $45.3 \%$ of the variance was explained by the five attributes.

\section{SUMMARY AND CONCLUSIONS}

The first research question for this study was determining what level of servant leadership was exhibited by professors in university classrooms. Based on this sample of 802 students in classrooms across the United States, the mean servant leadership traits exhibited was highest (exceeding an average of 3 meaning exhibiting sometimes) in emotional healing, wisdom, persuasive mapping, and organizational stewardship. This indicated that professors exhibited these servant leadership traits sometimes based on the average of total responses. Students on average perceived professors exhibiting altruistic traits "once in a while." Graduate students indicated their professors showed significantly higher levels of altruistic, wisdom, organizational stewardship, and performance mapping traits more than undergraduate students perceived their professors. We did not find differences in servant leadership attributes between male and female professors or between full-time and adjunct professors. However, non-business professors exhibited significantly higher levels of altruistic and emotional healing traits of servant leadership than business professors. There were no significant differences between non-business professors and business professors in wisdom, organizational stewardship, and persuasive mapping attributes of servant leadership.

The second research question examined the perceptions of quality of university instruction. The overall average of items relating to effective teaching indicated that students felt that quality of instruction was in the good to the satisfactory range. Students perceived nonbusiness professors as providing significantly more effective instruction than business professors. Students also perceived full-time faculty as providing more effective instruction than adjunct faculty. There were no differences in effective instruction between male and female faculty and no differences between undergraduate and graduate faculty.

The third research question examined the relationship between servant leadership and perceptions of the quality of university instruction. Based on the structural equation model analysis, there was a significant positive relationship $(\beta=.80, p<.01)$ between servant leadership attributes exhibited by university professors and quality of instruction. The more professors exhibited the servant-leadership attributes; the better students perceived the quality of instruction.

\section{IMPLICATIONS}

The sample size for the study consisted of 802 students across the United States. The students did not report whether they attended public or private institutions, as we looked to examine the general student population. Since student perception of servant leadership was positively related to student perception of quality instruction, academic faculty should examine their use of servant-leadership attributes in their interaction with students. While some servantleadership attributes were rated as used more often than others (emotional healing, wisdom, and persuasive mapping), there is still a need for improvement for all attributes. Graduate professors were perceived as better exhibiting these attributes than undergraduate professors. The maturity and experience of graduate students could impact this finding, as graduate students may better recognize servant-leadership behaviors than undergraduate students. Furthermore, we found that business school professors were not perceived as exhibiting servant-leadership attributes as well as non-business school professors. This was also true 
with the quality of instruction, as non-business school professors were perceived as providing better instruction. This study calls for needed improvement in business school professors through increased training and awareness of the servant-leadership attributes which could, in turn, improve quality of instruction.

\section{References}

Barbuto, J.E., et al. Scale development and construct clarification of servant leadership. Group \& Organization Management, 2006. 31(3): p. 300-326.

Beidler, P. G. What makes a good teacher? 1997, Boston, MA: Anker.

Bentler, P. M. (1990). Comparative fit indexes in structural models. Psychological Bulletin, 1990. 107: p. $238-246$.

Clark, J. Suggestions for effective university teaching, 1995. Retrieved from

http://ion.uwinnipeg.ca/ clark/acad/teach/effteach.html

Barbuto, J. E., et al. Examining gender differences of servant leadership: An analysis of the agentic and communal properties of the Servant Leadership Questionnaire. Journal of Leadership Education, 2010. 9(2): p. 4-22. Retrieved from http://www.leadershipeducators.org/resources/documents/jole/2010_summer/barbuto_and_gifford.pdf

Bowman, R. F. Teacher as servant leader, 2005, Philadelphia, PA: Heldref Publications

Burkhardt, J. C. Boundary-spanning leadership in higher education. Journal of Leadership Studies, 2002. 8(3): p. 145-150.

Dannhauser, Z., et al. Structural equivalence of the Barbuto and Wheeler (2006) Servant Leadership Questionnaire on North American and South African Samples. International Journal of Leadership Studies, 2007. 2(2): p. 148-168.

Greenleaf, R.K. The servant as leader, 1970, Indianapolis: The Robert K. Greenleaf Center.

Greenleaf, R.K. Servant leadership: A journey into the nature of legitimate power and greatness, 1977. New York, NY: Paulist Press.

Hays, J. M. Teacher as servant applications of Greenleaf's servant leadership in higher education. Journal of Global Business Issues, 2008. 2(1): p, 113-134.

Jennings, K., et al. The serving leader, 2003. San Francisco, CA: Berrett-Koehler.

Podsakoff, P. M. \& Organ, D. W. (1986). Self-reports in organizational research: Problems and prospects. Journal of Management, 1996. 12: p. 531-544.

Polleys, M. S. (2002). One university's response to the anti-leadership vaccine: Developing servant leaders. Journal of Leadership Studies, 2002. 8(3): p. 117-130.

Powers, J. B., et al. Servant-Leadership and the art of teaching. Voices of Servant-Leadership Series Booklet 11. Indianapolis, Indiana: The Greenleaf Center for Servant Leadership.

Ramsey, V. J., et al. Being in the classroom. Journal of Management Education, 2005. 29(2): p. 333-356.

Scardino, A. J. Servant Leadership in higher education: The Influence of servant-led faculty on student engagement. Dissertations \& Theses, 2013. Paper 25.

Spears, L. C. Creating caring leadership for the 21st century. The Not-For-Profit CEO Monthly Newsletter, 1998. 4(9). Indianapolis: The Robert K. Greenleaf Center for Servant-Leadership.

Steiger, J. H., et al. Statistically based tests for the number of common factors. Paper presented at the Annual Meeting of the Psychometric Society, 1980. Iowa City, IA.

Tucker, L. R. et al. A reliability coefficient for maximum likelihood factor analysis. Psychometrika, 1973. 38: p. 1-10.

Zohar, D. Rewiring the corporate brain: Using the new science to rethink how we structure and lead organizations, 1997. San Francisco, CA: Berrett-Koehler. 


\section{APPENDIX A \\ University of Winnipeg Qualities of University Instruction Questionnaire [4] Knowledge and Appreciation of Subject Items \\ - Encourages students to think for themselves and promotes intellectual curiosity. \\ - Expands students' knowledge and appreciation of the subject. \\ - Helps students develop skills related to the course (e.g., critical thinking, writing, ...).}

\section{Lesson Organization Items}

- Offers well-prepared and organized classes.

- Gives useful indicators for following lessons (e.g., outlines, states objectives, reviews main points, ...).

- Course elements (e.g., lectures, texts, readings, labs, ...) are integrated to help students appreciate and learn the course material.

\section{Items on Clear Explanations}

- Provides clear explanations for concepts and principles, with concrete examples where appropriate.

- Emphasizes major or difficult points (e.g., asks if students understand, repeats complex ideas, pauses, ...).

\section{Items on Clear Presentation}

- Speaks in a clear, well-paced, and expressive manner.

- Uses appropriate teaching aids effectively (e.g., blackboard, overhead projector, handouts, ...).

\section{Items on Stimulating Interest}

- Shows enthusiasm and interest in the course.

- Stimulates and maintains student interest.

\section{Items on Participation and Openness to New Ideas}

- Encourages student participation (e.g., asks questions, responds well to student questions or comments, ...).

- Respects alternative and challenging viewpoints.

\section{Items on Rapport and Concern}

- Treats students with respect in and out of class.

- Is available for consultation outside of class time.

- Is sensitive to whether students understand course material.

\section{Items on Communication and Fairness}

- Provides helpful feedback (e.g., useful comments on student work, takes up tests in class, ...).

- Evaluates students fairly (e.g., tests important material; gives reasonable work load; assigns appropriate percentages for term work, tests, and exams; ...).

- Marks and returns work in a reasonable time.

- Course objectives, assignments, and grading criteria are clear. (Appendix 1) 